\title{
Invasive Insect Species: Global Challenges, Strategies \& Opportunities
}

\author{
Robert C. Venette ${ }^{1,2 *}$ and William D. Hutchison ${ }^{2,3 *}$ \\ ${ }^{1}$ Forest Service, US Department of Agriculture, St. Paul, MN, United States, ${ }^{2}$ Minnesota Invasive Terrestrial Plants and Pests \\ Center, University of Minnesota, St. Paul, MN, United States, ${ }^{3}$ Department of Entomology, University of Minnesota, St. Paul, \\ MN, United States
}

Keywords: prediction, prevention, early detection, rapid response, integrated pest management, grand challenges, wicked problem, global development

Alien arthropods threaten human health, jeopardize food supplies, endanger valued species, risk economic losses, and disrupt ecosystem functions, at least some of the time. The accelerating pace of commercial and social globalization creates unprecedented opportunities for the movement of species to new areas of the world. As arthropods are dispersed beyond their native ranges, they escape population-regulating predators, parasitoids, and pathogens and encounter naive host plants and animals. In principle, the disruption of coevolutionary, antagonistic interactions presents an invading species with an opportunity to dominate and transform invaded areas, as evidenced, by grape phylloxera, Daktulosphaira vitifoliae, in Europe in the mid 1800's and emerald ash borer, Agrilus planipennis, in North America and Europe in the early 2000's. Nevertheless, invasion by severe pests remains an improbable happening, estimated at approximately one "success" for every 1,000 attempts (1). Thus, biological invasions represent low-probability, high-consequence events, predicaments to those who study or manage alien invasive pests.

Invasions involving arthropods are perhaps the most pervasive, underappreciated component of grand challenges to global development and prosperity, particularly to human health, nutritious food, clean water, resilient environments, and sustainable economies. Direct effects on food or the environment can be readily appreciated, as when fall armyworm, Spodoptera frugiperda, consumes maize in Africa (2), invasive flies, Philornis downsi, attack Darwin's finches in the Galapagos $(3,4)$, or red turpentine beetle, Dendroctonus valens, kills expanses of pine in China (5). Indirect effects may be more cryptic, as when brown marmorated stink bug, Halyomorpha halys, vectors aflatoxinproducing fungi in the USA (6), spittlebugs spread the non-native bacterium Xylella fastidiosa (7), or Asian tiger mosquito, Aedes albopictus, transmits dengue viruses in South America (8). Further indirect effects to health, water, and the environment can arise through responses to arthropod invasions, especially if intensive pesticide use becomes necessary (9). Perhaps least appreciated are the barriers invasive arthropods present to economic advancement in developing nations when demonstrable phytosanitary concerns preclude or curtail international trade in plant-based commodities from those nations to global markets. Thus, solutions to the problem of arthropod invasions are needed to achieve diverse, humanitarian goals.

We are excited about this opportunity to support a new venue for publishing research and conceptual ideas, with a focus on invasive arthropods. C.S. Elton (10), the founder of modern invasion biology, provided numerous insect examples among others to highlight commonalities of the invasion process. Recent reviews feature promising areas for invasive species research in general and emphasize the value of studying across spatiotemporal scales, collaborating with international partners, engaging the public, and considering interactions with climate change or other environmental stressors $(11,12)$. We believe a renewed, clear emphasis on arthropod invasions will accelerate progress for entomologists and invasion biologists alike. The purpose of this overview is to highlight current challenges and offer a vision for moving the field of invasive arthropod species ecology and management forward via insightful articles that not only present 
new research but also challenge long-held theory and practice relevant to invasive species biology, ecology and management. We are motivated not by the novelty, but by the consequences, of new species in new environments. We seek answers that are well-grounded in theory and rigorously tested in practice.

\section{GRAND CHALLENGES FOR INVASIVE INSECT SCIENCE}

Invasion biology is inherently an applied discipline, and the core questions remain: (1) which species are most likely to invade; (2) where are invasions most likely to be successful; and (3) how can this information be used "to best advantage" to manage biological invasions (13)? As invasions progress through the phases of arrival, establishment, and spread, management strategies change from prediction and prevention, to early detection and rapid response, to mitigation and management. Bioeconomic analyses generally confirm that efforts to prevent or contain invasions are more cost-effective than efforts to mitigate damage or restore ecosystems after invasion has occurred $(14,15)$.

Alien invasive species are what sociologists call a "wicked" problem with multiple causes (e.g., international trade, phytosanitary breakdowns, climate change, public unawareness, etc.), each defying a simple, outright solution $(16,17)$. Researchers can help tame the invasive species problem by addressing goals with strong public support and tangible metrics of success. The value of a proposed solution (e.g., new sampling plan or control technology) should be transparent and highlight the costs and benefits relative to current practice.

\section{Prediction and Prevention}

Prediction and prevention remain the most lauded approach to address alien invasive species. The intent seems simple enough: forecast which species or pathways pose unacceptable risks and keep them from arriving in an area of concern. This strategy requires a clear benchmark of success. As the number of introduced arthropod species continues to increase at a steady rate, each new incursion might be viewed as evidence of a biosecurity failure (11). However, global trade has increased more rapidly than species arrivals, a pattern that suggests biosecurity efforts have been somewhat effective (17) but is far from a clear measure of achievement (18).

We see promise in future systems integration to forecast threats and prevent introductions. We remain optimistic that advances in horizon scanning and real-time global pest surveillance can provide more dynamic representations of encroaching threats $(19,20)$. We see opportunities in systems approaches to keep invasive alien insects out of supply chains for goods destined for foreign markets. Advances in commodity disinfestation technologies remain needed, with alternatives to methyl bromide still a priority (21). In addition, more sophisticated tools, perhaps based on environmental DNA or volatile chemical profiles, are needed to detect insects en route $(22,23)$.

Spatially-explicit pest risk assessment will remain a cornerstone of biosecurity efforts both to inform the permissibility of a good for import, to structure surveillance programs, and to conduct post incursion responses should a species arrive within an endangered area (24). These assessments generally describe where a species is most likely to invade and/or cause harm, often focusing on conditions needed for pest establishment. However, approaches for developing these assessments are needed that are reliable, scalable, and affordable. The conceptual challenge of developing models that are reliably transferable to new space and time is becoming increasingly recognized, particularly for machine learning and other statistical models (25). Process-based models have appeal, but extensive data requirements make the approach prohibitive for application to the hundreds, if not thousands, of species of concern (26). Advances in the democratization of data collection through apps and open access databases improve capacity to capture changes in distribution, abundance, and phenology of insect populations. Developments in phylogeography will provide a more detailed accounting of invasions, identify invasive phenotypes, and more explicitly account for genotype $\mathrm{x}$ environment interactions to improve the rigor of forecasts (27-29).

\section{Early Detection and Rapid Response}

Should prediction and prevention efforts fail, the next best alternative is to locate nascent populations of high-risk species early and eradicate or contain them quickly. Despite the global development of methods for early detection of invasive insects, initial observations of alien species in both agricultural and forest systems are still too often fortuitous (17). Research to improve this strategy is needed to address where/when/how to look for new invasive species and how to confirm their identity if encountered.

Pest risk maps highlight areas where species might invade or cause harm, and as such, provide useful direction about areas to consider for early-detection surveys. The endangered area may be too large to survey effectively with available resources. We believe more research is needed to quantify the probability of detecting low densities of invasive arthropods with a particular sampling scheme (30). A "risk-based surveillance" approach has been developed for plant pathogens that targets sampling effort where most preferred and valuable host plants occur (31). The cost of invasive species detection can therefore be reduced, yet more research is needed to examine this approach for invasive insects. Yemshanov et al. $(32,33)$ have taken spatial optimization of sampling effort to a new level, but the methods can be computationally intensive to apply.

Within endangered areas, the next major challenge becomes how to sample for the early detection of targeted species. Sentinel plots of appropriate plant species can be used effectively to detect species or suites of invasive arthropods that share a common host, for example, maize (34) or maples (35). The deployment of traps, particularly when appropriate semio-chemical lures are available, remains a preferred monitoring option because traps are more convenient and cost-effective than visual inspections. Nevertheless, visual inspections may be unavoidable if lures are unavailable or traps become impractical. Citizen science to assist with trap monitoring or visual inspection has been embraced for the early detection of spotted-wing drosophila, Drosophila 
suzukii, in the United States (36) and the multicolored Asian lady beetle, Harmonia axyridis, in Europe (37), for example.

Recent advances in genomics, bolstered by traditional taxonomic expertise, offer a path to rapid confirmation of species identity. An additional advantage of genomic approaches is that various strains, biotypes or haplotypes can be distinguished within a species. Specific haplotype data can thereby reflect more precisely the geographic origins of an invasive population, as demonstrated for walnut twig beetle, Pityophthorus juglandis (38), H. halys (39), and S. frugiperda (40). With accurate knowledge of pest origins, specific countries can be targeted early in the search for natural enemies, usually species-specific parasitoids, for subsequent safety and efficacy evaluation and release for biological control within the invaded countries (41).

\section{Management and Mitigation}

Following early establishment and spread of invasive arthropods, immediate investment in research and development to support integrated pest management (IPM) solutions continues to be a valid paradigm. IPM is "an ecosystem-based strategy that focuses on long-term prevention of pests or their damage through a combination of techniques such as biological control, habitat manipulation, modification of cultural practices, and use of resistant varieties. Pesticides are used only after monitoring indicates they are needed according to established guidelines, and treatments are made with the goal of removing only the target organism. Pest control materials are selected and applied in a manner that minimizes risks to human health, beneficial and non-target organisms, and the environment" (42). Areawide pest management extends these decision-making principles beyond individual farms or landholdings.

Ironically, for many cropping systems, IPM is often in place for endemic pests when invasive pests arrive. Some arrivals disrupt existing IPM programs where biological control and/or reduced-risk insecticides are being used; $H$. halys in U.S. apple production is a prime example, where $>\$ 37$ million was lost due to damage and increased insecticide application costs (43).

\section{REFERENCES}

1. Williamson M, Fitter A. The varying success of invaders. Ecology. (1996) 77:1661-6. doi: 10.2307/2265769

2. Sileshi GW, Gebeyehu S, Mafongoya PL. The threat of alien invasive insect and mite species to food security in Africa and the need for a continent-wide response. Food Secur. (2019) 11:763-75. doi: 10.1007/s12571-019-00930-1

3. Fessl B, Tebbich S. Philornis downsi - a recently discovered parasite on the Galapagos archipelago - a threat for Darwin's finches? Ibis. (2002) 144:445-51. doi: 10.1046/j.1474-919X.2002.00076.x

4. Koop JAH, Causton CE, Bulgarella M, Cooper E, Heimpel GE. Population structure of a nest parasite of Darwin's finches within its native and invasive ranges. Conserv Genet. (2020) 2020. doi: 10.1007/s10592-020-01315-0

5. Sun JH, Lu M, Gillette NE, Wingfield MJ. Red turpentine beetle: innocuous native becomes invasive tree killer in China. Annu Rev Entomol. (2013) 58:293-311. doi: 10.1146/annurev-ento-120811-153624

6. Opoku J, Kleczewski NM, Hamby KA, Herbert DA, Malone S, Mehl HL. Relationship between invasive brown marmorated stink bug (Halyomorpha halys) and fumonisin contamination of field corn in the Mid-Atlantic U.S. Plant Dis. (2019) 103:1189-95. doi: 10.1094/PDIS-06-18-1115-RE

7. Occhibove F, Chapman DS, Mastin AJ, Parnell SSR, Agstner B, Mato-Amboage $\mathrm{R}$, et al. Eco-epidemiological uncertainties of
As with endemic pests, the IPM response to invasive species typically requires both near-term and long-term strategies. To protect grower investments, the initial focus is often insecticidal control, with simultaneous commitments to fund research on biological control, pest-resistant varieties, cultural controls (44), physical exclusions (45), and "attract and kill” trap-based systems based on insect behavior (46). Breeding for resistance to invasive pests is increasingly important for trees and perennial crops. Transgenic insecticidal plants (47) or genetic biocontrol agents $(48,49)$, as through gene-drives, are novel technologies that could supplement or supplant IPM programs, pending requisite regulatory approvals.

\section{CONCLUSIONS}

We look forward to hosting the first journal with a section fully devoted to invasive arthropod biology, ecology and management. Broadly, we envisage papers focused on invasive arthropods of current or future significance to human health, agriculture, forestry, or natural ecosystems. We welcome comprehensive research, review, and perspective articles that address impacts of invasive arthropods on food security, global trade, forest and ecosystem health, biodiversity, crop protection, public health and recreation, and policy. Specifically for Frontiers in Insect Science, our section encourages papers in population/community and landscape ecology, population genetics and evolutionary biology, pest risk assessment and mapping, the intersection of invasive species spread and global climate change, novel methods for early detection, biological control, genetic biocontrol, area-wide integrated pest management, and economic and environmental impacts. We look forward to the journey!

\section{AUTHOR CONTRIBUTIONS}

$\mathrm{RV}$ and $\mathrm{WH}$ were the sole contributors to this manuscript. Both authors contributed to the article and approved the submitted version.

emerging plant diseases: the challenge of predicting Xylella fastidiosa dynamics in novel environments. Phytopathology. (2020) 110:1740-50. doi: 10.1094/PHYTO-03-20-0098-RVW

8. Rezende HR, Romano CM, Claro IM, Caleiro GS, Sabino EC, Felix $\mathrm{AC}$, et al. First report of Aedes albopictus infected by dengue and zika virus in a rural outbreak in Brazil. PLOS ONE. (2020) 15:e0229846. doi: 10.1371/journal.pone.0229847

9. Milano M, Chevre N. How water quality standards for pesticides affect the classification of the chemical status of rivers. Wiley Interdiscip Rev Water. (2019) 6:12. doi: 10.1002/wat2.1375

10. Elton CS. The Ecology of Invasions by Animals and Plants. London: Methuen (1958). doi: 10.1007/978-1-4899-7214-9

11. Pysek P, Hulme PE, Simberloff D, Bacher S, Blackburn TM, Carlton JT, et al. Scientists' warning on invasive alien species. Biol Rev. (2020) 95:1511-34. doi: $10.1111 /$ brv.12627

12. Poland TM, Patel-Weynand T, Finch D, Miniat CF, Hayes DC, Lopez VM. Invasive Species in Forests and Rangelands of the United States. New York, NY: Springer (2021). doi: 10.1007/978-3-030-45367-1

13. Williamson MH, Brown KC. The analysis and modeling of British invasions. Philos Trans R Soc Lond B. (1986) 314:505-22. doi: 10.1098/rstb.1986.0070

14. Leung B, Lodge DM, Finnoff D, Shogren JF, Lewis MA, Lamberti G. An ounce of prevention or a pound of cure: bioeconomic risk analysis of 
invasive species. Proc R Soc B. (2002) 269:2407-13. doi: 10.1098/rspb.2002. 2179

15. Lampert A, Liebhold AM. Combining multiple tactics over time for costeffective eradication of invading insect populations. Ecol Lett. (2021) 24:27987. doi: $10.1111 /$ ele. 13640

16. McNeely JA. Global efforts to address the wicked problem of invasive alien species. In: Foxcroft LC, Pysek P, Richardson DM, Genovesi P, editors. Plant Invasions in Protected Areas: Patterns, Problems and Challenges. New York, NY: Springer (2013). p. 61-71. doi: 10.1007/978-94-007-7750-7_4

17. Venette RC, Morey AC. Advances in understanding the ecology of invasive crop insect pests and their impact on IPM. In: Kogan M, Heinrichs EA. Integrated Management of Insect Pests: Current and Future Developments. Cambridge, UK: Burleigh Dodds Science Publishing. (2020). p. 161-90. doi: 10.19103/AS.2019.0047.06

18. Saccaggi DL, Karsten M, Robertson MP, Kumschick S, Somers MJ, Wilson JRU, et al. Methods and approaches for the management of arthropod border incursions. Biol Invasions. (2016) 18:1057-75. doi: 10.1007/s10530-016-1085-6

19. Poland TM, Rassati D. Improved biosecurity surveillance of non-native forest insects: a review of current methods. J Pest Sci. (2019) 92:37-49. doi: 10.1007/s10340-018-1004-y

20. Roy HE, Bacher S, Essl F, Adriaens T, Aldridge DC, Bishop JDD, et al. Developing a list of invasive alien species likely to threaten biodiversity and ecosystems in the European Union. Glob Change Biol. (2019) 25:1032-48. doi: $10.1111 /$ gcb.14527

21. Kim BS, Park CG, Moon YM, Sung BK, Ren Y, Wylie SJ, et al. Quarantine treatments of imported nursery plants and exported cut flowers by phosphine gas (PH3) as methyl bromide alternative. J Econ Entomol. (2016) 109:2334-40. doi: 10.1093/jee/tow200

22. Lucas JA. Advances in plant disease and pest management. J Agric Sci. (2011) 149:91-114. doi: 10.1017/S0021859610000997

23. Larson ER, Graham BM, Achury R, Coon JJ, Daniels MK, Gambrell DK, et al. From eDNA to citizen science: emerging tools for the early detection of invasive species. Front Ecol Environ. (2020) 18:194-202. doi: 10.1002/fee.2162

24. Venette RC, Kriticos DJ, Magarey RD, Koch FH, Baker RHA, Worner SP, et al. Pest risk maps for invasive alien species: a roadmap for improvement. Biosci. (2010) 60:349-62. doi: 10.1525/bio.2010.60.5.5

25. Morey AC, Venette RC. Minimizing risk and maximizing spatial transferability: challenges in constructing a useful model of potential suitability for an invasive insect. Ann Entomol Soc Am. (2020) 113:100-13. doi: 10.1093/aesa/saz049

26. Venette RC. Climate analyses to assess risks from invasive forest insects: simple matching to advanced models. Curr Forestry Rep. (2017) 3:255-68. doi: 10.1007/s40725-017-0061-4

27. Estoup A, Guillemaud T. Reconstructing routes of invasion using genetic data: why, how and so what? Mol Ecol. (2010) 19:4113-30. doi: 10.1111/j.1365-294X.2010.04773.x

28. Cristescu ME. Genetic reconstructions of invasion history. Mol Ecol. (2015) 24:2212-25. doi: 10.1111/mec.13117

29. Roe AD, Torson AS, Bilodeau G, Bilodeau P, Blackburn GS, Cui MM, et al. Biosurveillance of forest insects: part I - integration and application of genomic tools to the surveillance of non-native forest insects. J Pest Sci. (2019) 92:51-70. doi: 10.1007/s10340-018-1027-4

30. Venette RC, Moon RD, Hutchison WD. Strategies and statistics of sampling for rare individuals. Ann Rev Entomol. (2002) 47:143-74. doi: 10.1146/annurev.ento.47.091201.145147

31. Mastin AJ, Gottwald TR, van den Bosch F, Cunniffe NJ, Parnell S. Optimising risk-based surveillance for early detection of invasive plant pathogens. PLoS Biol. (2020) 18:e3000863. doi: 10.1371/journal.pbio.3000863

32. Yemshanov D, Haight RG, Koch FH, Lu B, Venette R, Fournier $\mathrm{RE}$, et al. Robust surveillance and control of invasive species using a scenario optimization approach. Ecol Econ. (2017) 133:86-98. doi: 10.1016/j.ecolecon.2016.11.018

33. Yemshanov D, Haight RG, Koch FH, Venette RC, Swystun T, Fournier RE, et al. Optimizing surveillance strategies for early detection of invasive alien species. Ecol Econ. (2019) 162:87-99. doi: 10.1016/j.ecolecon.2019.04.030

34. O'Rourke PK, Hutchison WD. First report of the western bean cutworm, Richia albicosta (Smith) (Lepidoptera : Noctuidae), in Minnesota corn. J Agric Urban Entomol. (2000) 17:213-7.
35. Britton KO, White P, Kramer A, Hudler G. A new approach to stopping the spread of invasive insects and pathogens: early detection and rapid response via a global network of sentinel plantings. N Z J Forestry Sci. (2010) 40:109-14.

36. Asplen MK, Anfora G, Biondi A, Choi DS, Chu D, Daane KM, et al. Invasion biology of spotted wing drosophila (Drosophila suzukii): a global perspective and future priorities. J Pest Sci. (2015) 88:469-94. doi: 10.1007/s10340-015-0681-z

37. Roy HE, Brown PMJ, Adriaens T, Berkvens N, Borges I, Clusella-Trullas $\mathrm{S}$, et al. The harlequin ladybird, Harmonia axyridis: global perspectives on invasion history and ecology. Biol Invasions. (2016) 18:997-1044. doi: 10.1007/s10530-016-1077-6

38. Rugman-Jones PF, Seybold SJ, Graves AD, Stouthamer R. Phylogeography of the walnut twig beetle, Pityophthorus juglandis, the vector of thousand cankers disease in North American walnut trees. PLOS ONE. (2015) 10:e0118264. doi: 10.1371/journal.pone.0118264

39. Xu JW, Fonseca DM, Hamilton GC, Hoelmer KA, Nielsen AL. Tracing the origin of US brown marmorated stink bugs, Halyomorpha halys. Biol Invasions. (2014) 16:153-66. doi: 10.1007/s10530-013-0510-3

40. Goergen G, Kumar PL, Sankung SB, Togola A, Tamo M. First report of outbreaks of the fall armyworm Spodoptera frugiperda (J E Smith) (Lepidoptera, Noctuidae), a new alien invasive pest in West and Central Africa. PLoS ONE. (2016) 11:9. doi: 10.1371/journal.pone.0165632

41. Wyckhuys KAG, Lu Y, Zhou W, Cock MJW, Naranjo SE, Fereti A, et al. Ecological pest control fortifies agricultural growth in AsiaPacific economies. Nat Ecol Evol. (2020) 4:1522. doi: 10.1038/s41559-02001294-y

42. UC IPM. What is Integrated Pest Management (IPM)?. Davis, CA: University of California, College of Agriculture and Natural Resources (1996). Available online at: https://www2.ipm.ucanr.edu/What-is-IPM/ (accessed December 13, 2020).

43. Leskey TC, Nielsen AL. Impact of the invasive brown marmorated stink bug in North America and Europe: history, biology, ecology, and management. Annu Rev Entomol. (2018) 63:599-618. doi: 10.1146/annurev-ento-020117-043226

44. Radcliffe EB, Hutchison WD, Cancelado R. Integrated Pest Management: Concepts, Tactics, Strategies and Case Studies. UK: Cambridge University Press (2009). doi: 10.1017/CBO9780511626463

45. Rogers MA, Burkness EC, Hutchison WD. Evaluation of high tunnels for management of Drosophila suzukii in fall-bearing red raspberries: potential for reducing insecticide use. J Pest Sci. (2016) 89:815-21. doi: 10.1007/s10340-016-0731-1

46. Gregg PC, Del Socorro AP, Landolt PJ. Advances in attract-and-kill for agricultural pests: beyond pheromones. Annu Rev Entomol. (2018) 63:453-70. doi: 10.1146/annurev-ento-031616-035040

47. Hutchison WD, Burkness EC, Mitchell PD, Moon RD, Leslie TW, Fleischer SJ, et al. Areawide suppression of European corn borer with Bt maize reaps savings to non-Bt maize growers. Science. (2010) 330:222-5. doi: 10.1126/science.1190242

48. Maselko M, Heinsch SC, Chacon JM, Harcombe WR, Smanski MJ. Engineering species-like barriers to sexual reproduction. Nat Commun. (2017) 8:7. doi: 10.1038/s41467-017-01007-3

49. Sudweeks J, Hollingsworth B, Blondel DV, Campbell KJ, Dhole S, Eisemann JD, et al. Locally fixed alleles: a method to localize gene drive to island populations. Sci Rep. (2019) 9:10. doi: 10.1038/s41598-019-51994-0

Disclaimer: The findings and conclusions in this publication are those of the authors and should not be construed to represent any official USDA or U.S. Government determination of policy.

Conflict of Interest: The authors declare that the research was conducted in the absence of any commercial or financial relationships that could be construed as a potential conflict of interest.

Copyright (c) 2021 Venette and Hutchison. This is an open-access article distributed under the terms of the Creative Commons Attribution License (CC BY). The use, distribution or reproduction in other forums is permitted, provided the original author(s) and the copyright owner(s) are credited and that the original publication in this journal is cited, in accordance with accepted academic practice. No use, distribution or reproduction is permitted which does not comply with these terms. 